\title{
Lepidoptera from the Pantepui. Part VII. A distinctive Lamprospilus species from the Guiana Highlands (Lepidoptera: Lycaenidae: Theclinae)
}

\author{
M. Costa $^{1}$, Á.L. Viloria ${ }^{2}$, S. AtTAL $^{3}$, M. Benmesbah ${ }^{4}$, S. Fratello $^{5} \&$ Zs. BÁlint $^{6}$ \\ ${ }^{1}$ Mauro Costa, Res. Las Cumbres, Av. Las Acacias, La Florida, Caracas 1020-A, Venezuela, \\ Email: mauro13x50@gmail.com \\ ${ }^{2}$ Ángel L. Viloria, Centro de Ecología, Instituto Venezolano de Investigaciones Científicas (IVIC), Apartado \\ Postal 20632, Caracas 1020-A, Venezuela. Email: aviloria@ivic.gob.ve \\ ${ }^{3}$ Stéphane Attal, 5-15 rue Olivier-Noyer, 75014 Paris, France.Email: stephane.attal@,wanadoo fr \\ ${ }^{4}$ Mohamed Benmesbah, Impasse du Loudet, villa 3, F-31770 Colomiers, France \\ Email: modjojojo66@hotmail.com \\ ${ }^{5}$ Steve Fratello, 11 First St, W. Islip, NY 11795, USA. Email: sfratell@,suffolk.lib ny.us \\ ${ }^{6}$ Zsolt Bálint, Hungarian Natural History Museum, Department of Zoology,H-1088 Budapest, Baross utca 13, \\ Hungary. Email: balint.zsolt@,nhmus hu
}

\begin{abstract}
Lamprospilus ayawi sp. nov. (Lycaenidae, Theclinae), whose male possesses distinctive transparent wing patches, is described from the Guiana Highlands of South America, on the basis of six males and five females from Venezuela (Auyán and Sororopán Tepuis) and one male from Guyana (Acarai Mts.).

Resumen. Lamprospilus ayawi sp. nov. (Lycaenidae, Theclinae), cuyo macho presenta porciones transparentes distintivas en las alas, se describe de las Tierras Altas del Escudo Guayanés en Suramérica, sobre la base de seis machos y cinco hembras de Venezuela (Auyán y Sororopán Tepui) y de un macho de Guyana (Montes Acarai).
\end{abstract}

Keywords. Calycopidina, Eumaeini, hyaline wing surface, Neotropical, sexual dimorphism.

\section{INTRODUCTION}

$\mathrm{T}$ he Guiana Shield is a geological formation, presumed very ancient Precambrian basement rock, that underlies a large region of northern South America: south and southeastern Venezuela, Guyana, Surinam, French Guiana and adjacent areas of Brazil and Colombia. The Guiana Highlands (used here strictly in a physiographic sense) includes all the uplands of the Guiana Shield and can be divided into three areas: the Guiana Highlands proper, the Tumucumaque Uplands and the Chiribiquete Plateau ( $c f$. Rull et al. 2019). The latter area is in Colombia on the western edge of the Guiana Shield and outside the scope of this manuscript. Encompassing all the highlands of southern and southeastern Venezuela, adjoining northwestern Guyana and adjacent Brazil, the Guiana Highlands proper are the predominant mountainous region of the Guiana Highlands and manifest by far its highest elevation (up to nearly $3000 \mathrm{~m}$ ). The dominant physiographical feature of this region is the numerous tepuis, many being sheer-sided table mountains composed of sedimentary rock. Auyán Tepui is an impressive quintessential table mountain, a simply stupendous landform, rising high above its surroundings (from $500 \mathrm{~m}$ to $2,450 \mathrm{~m}$ ) and with an immense summit plateau of $667 \mathrm{~km}^{2}$. Sororopán Tepui, a much smaller mountain compared to Auyán Tepui, is part of the Ptarí Massif and is located at the west end of the Sierra de Lema; densely covered by forest, it consists of a $10 \mathrm{~km}$ slightly inclined ridge (from the base at $1400 \mathrm{~m}$ to 
the top at $2050 \mathrm{~m}$ ) with a steep wall only on its southern face. The Pantepui is a biogeographic province (Costa et al. 2014b, Morrone 2014, 2017) and comprises the biota above approximately $1,000 \mathrm{~m}$ of the Guiana Highlands proper. Known for its high endemicity among numerous biotic groups, a team of lepidopterists has been involved in the exploration and the study of the Lepidoptera of the Pantepui; the work is still ongoing (Costa et al. 2014a, 2014b, 2016, 2017, 2018, 2019).

The Tumucumaque Uplands includes the uplands of the southern Guianas (Guyana, Suriname and French Guiana) and adjacent Brazil, and also the mountains of central Suriname. These ranges are predominantly east-west oriented, largely composed of metamorphic/igneous rocks and with the highest elevation in this region close to 1300 $\mathrm{m}$. The Acarai Mountains are on the Guyana-Brazilian border, highest elevation in this range close to $1200 \mathrm{~m}$. Many of the ranges of the Tumucumaque Uplands are very remote and even less explored than the tepuis (Fratello 2003, 2005). Whether the relatively small area of the Tumucumaque Uplands above approximately $1,000 \mathrm{~m}$ should be considered part of the Pantepui province is a study in its infancy and will be discussed later in this manuscript.

Fratello (2005) reported on the occurrence of a spectacular and distinctive hairstreak with transparent wing patches collected in the Acarai Mountains of Guyana. The single specimen was documented and discussed in detail and was identified as an undescribed species of Lamprospilus Geyer, [1832] (Fratello 2005), a calycopidine hairstreak (Duarte \& Robbins 2010). This species remained hitherto unnamed. Recently, six males and five females of the same species have been collected by two of us (MC and MB) on the slopes of the Sororopán and Auyán Tepuis in Venezuela.

Calycopidine hairstreaks represent one of the most diverse groups of Eumaeini, a tribe constituting more than $90 \%$ of the Lycaenidae fauna in South America (Robbins 2004). In the Neotro- pical checklist, Robbins (2004) recognized a "Lamprospilus section" with seven genera, placing therein 157 species; 35 of these were remarked as unnamed, bearing the epithet "[n. sp.] Robbins, MS". Subsequently, this section has been revised and named as subtribe Calycopidina by Duarte \& Robbins (2010), now constituting ten genera. As they stressed, the most remarkable character of the members of this subtribe is their larval detritivory.

One of the calycopidine genera is Lamprospilus, a poorly known genus established by monotypy. This genus-group name has traditionally been associated with species possessing large hyaline or white patches ( $c f$. Draudt 1920, Lathy 1932), but D'Abrera (1995) widened the concept, combining many names conditionally with Lamprospilus, that formerly were placed in Thecla Fabricius, 1807. In the aforementioned checklist (Robbins 2004), the genus included 41 species (15 unnamed). Duarte \& Robbins (2010) redescribed and revised the genus, listing three characters for distinguishing Lamprospilus from the rest of the Calycopidina, and reduced the number to ten described, plus four-five undescribed species.

The purpose of the present paper is to name, describe and discuss a new calycopidine hairstreak butterfly, as yet only found in the Guiana Highlands. The discussion includes the placement of this species within Lamprospilus, its sexual dimorphism including evidence supporting their conspecificity, the peculiarity and hypotheses regarding the male phenotype and considerations on butterfly endemism and biogeography.

\section{MATERIALS AND METHODS}

Acronyms: $\mathrm{CF}=$ Christophe Faynel, Montaud, France; $\mathrm{HNHM}=$ Hungarian National History Museum, Budapest; $\mathrm{MB}=$ Mohamed Benmesbah, Toulouse, France; $\mathrm{MC}=$ Mauro Costa, Caracas, Venezuela; MIZA = Museo del Instituto de Zoología Agrícola, Facultad de Agronomía, Universidad Central de Venezuela, Maracay; NHMUK = Natural History Museum United Kingdom, London; PB = Pierre Boyer, Le Puy Sainte Reparade, 
France; SF $=$ Steven Fratello, New York, USA; USNM = United States National Museum, Smithsonian Institution, Washington, DC; ZB = Zsolt Bálint, HNHM, Budapest.

About 850 calycopidine specimens were examined in the HNHM for comparative purposes. The digital documentation of 81 Lamprospilus specimens deposited in the private collection of PB was also studied. Relevant Lamprospilus type material was examined by ZB in the NHMUK ( $c f$. Bálint \& Goodger 2003, Bálint 2005); when necessary, we consulted the images of type specimens on the web-site Butterflies of America (Warren et al. 2018). Depository of type specimens is indicated in the Type material entry.

For morphological studies we used standard entomological techniques (Winter 2000). Specimens were set and digitally documented in the private laboratory of Stéphane Attal (Paris, France), and were put on loan for the HNHM (coll. Lepidoptera, 2017-25). Abdomens were dissected in the HNHM laboratory, inventoried with serial numbers of Zsolt Bálint (,gen. prep. nos”) and the preparations are being kept with the relevant specimens in plastic microvials filled with glycerin. In the HNHM, an Olympus 70SZX12 optical stereo microscope was used to examine specimen anatomy; for digitalisation, an Olympus DP70 digital camera attached to the microscope was used.

Nomenclature for wing pattern and genitalia is compatible with other recent studies of the Calycopidina (cf. Duarte \& Robbins 2010, Robbins \& Duarte 2010).

\section{RESULTS}

\section{Genus Lamprospilus Geyer, [1832]}

\section{Lamprospilus ayawi Bálint, Fratello, Costa \& Benmesbah, sp. nov.}

(Figures 1-7, 9-14)

Lamprospilus [n. sp.] Robbins MS; Robbins 2004: 127. Lamprospilus Geyer n. sp. (Fratello, in prep.); Fratello 2005: 34-35, 37 figs. 10 (male recto), 11 (male verso), $12 \mathrm{~d}$ (male recto).
Material examined $(\mathrm{n}=12)$. Holotype $\widehat{\delta}(\mathrm{set}$ dorsally, in perfect condition), Venezuela, Bolívar, Auyán Tepui, El Danto, 1500 m, 18.I.2017, $05^{\circ} 43^{\prime} 50^{\prime \prime} \mathrm{N}, 62^{\circ} 32^{\prime} 27^{\prime \prime} \mathrm{W}, \mathrm{M}$. Costa, \& M. Benmesbah (MIZA) (Figs. 1-2). Paratype (allotype) , Venezuela, Bolívar, Auyán Tepui, El Peñón, $1850 \mathrm{~m}, 29 . \mathrm{I} .2019,05^{\circ} 44^{\prime} 40^{\prime \prime} \mathrm{N}, 62^{\circ} 32^{\prime} 27^{\prime \prime} \mathrm{W}, \mathrm{M}$. Costa \& M. Benmesbah (MIZA) (Figs. 3-4). Further paratypes $(6 \hat{\jmath} \widehat{\partial}, 4$ 우): $1 \hat{\jmath}$, Guyana: Acarai Mts./Ridge, Sipu River 2500-3000 ft, 31.X.-10.XI.2000, $1^{\circ} 22.2^{\prime} \mathrm{N}, 58^{\circ} 47.91^{\prime} \mathrm{W}, \mathrm{S}$. Fratello et al. (USNM) (Figs. 5-6); 10, idem holotype, 19.I.2017 (MB); 2ภํ, Venezuela, Bolívar, Auyán Tepui, entre Guayaraca y El Danto, 1400

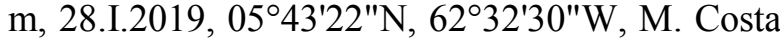
\& M. Benmesbah (1 MIZA, $1 \mathrm{CF}) ; 1 \hat{\jmath}$, idem, (HNHM); 10ิ, idem, (MC); 19, idem allotype (MIZA); 19, idem allotype (MIZA); 19 , Venezuela, Bolívar, Sororopán Tepui, 1650 m, 19.VII. 2014, 542'08"N, 61 ${ }^{\circ} 47^{\prime} 06^{\prime \prime W}$, M. Costa (HNHM); 19 , idem (MC).

Classification and generic placement. This species belongs to the tribe Eumaeini because it possesses the following three diagnostic characters: (1) ten forewing veins; (2) greyhoundshaped male genitalia without a sclerotized juxta; (3) male foretarsus fused and stubby tipped, used for walking (Eliot 1973). It is placed in the genus Lamprospilus (type species: Lamprospilus genius Geyer, [1832], by monotypy) because in the middle of the male genitalia gnathos, there is a single medium-sized tooth (Fig. 7, see also Duarte \& Robbins 2010). Lastly, it is allied to the Lamprospilus genius species group (Lamprospilus sensu stricto), because the male forewing surface between veins $\mathrm{M} 3$ and $\mathrm{CuA} 2$ is partly, either hyaline without (or little) scaling or is covered by white scales ( $c f$. Fig. 8).

Diagnosis. Within Lamprospilus there is a lineage of species having male phenotypes with hyaline or white bands across the wings (Duarte \& Robbins 2010, fig. 61). The most similar in wing facies and the probable two closest relatives of $L$. ayawi are the hyaline patterned: L. genius (documented by D'Abrera 1995: p. 1099), a widespread Amazonian species, and the southeast Brazilian L. japola (E. Jones, 1912) (Figs. 1-2, 


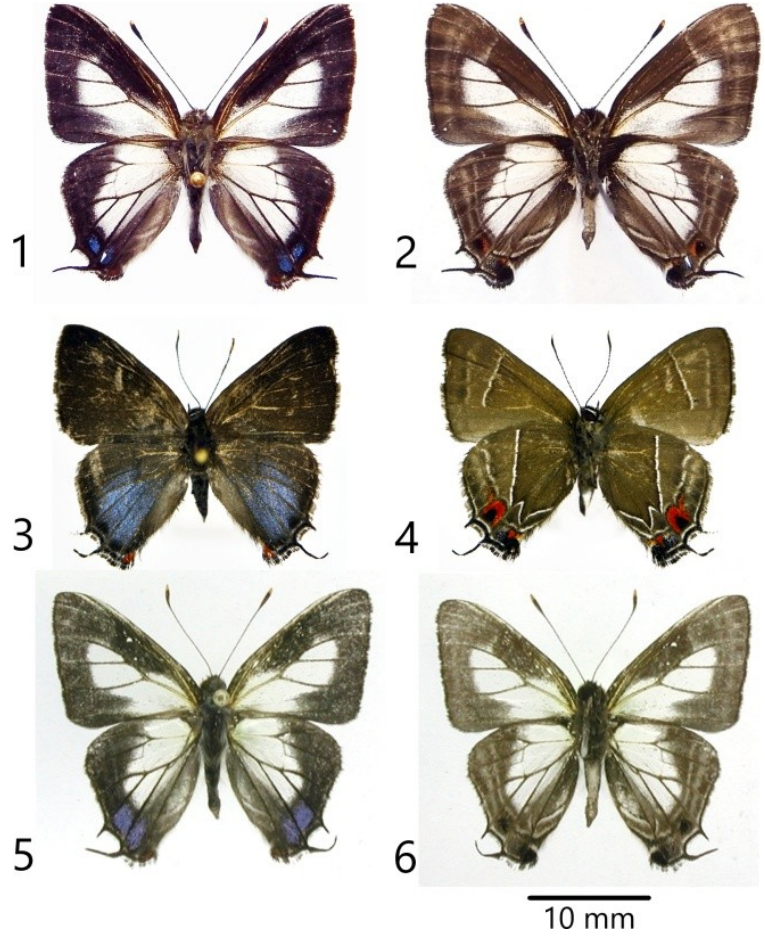

Figures 1-6. Lamprospilus ayawi sp. nov. adults. $1=$ holotype male, recto; 2 = idem, verso; 3 = allotype female, recto; $4=$ idem, verso; 5 = paratype male form Acarai Mountains, recto; 6 = idem, verso (for scale see the main text).
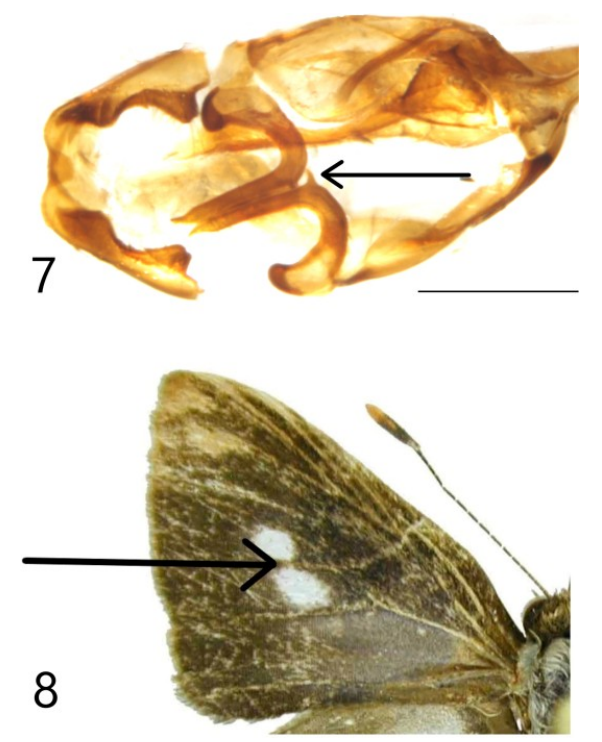

Figures 7-8. Two Lamprospilus characters, examples from $L$. ayawi sp. nov. and $L$. genius Geyer, $1832 ; 7=$ the single medium-sized tooth in the middle of the L. ayawi male genitalia gnathos indicated by arrow (scale bar: $0.6 \mathrm{~mm}$ ); $8=$ hyaline male forewing surface pattern between veins $\mathrm{M} 3$ and $\mathrm{CuA} 2$ in L. genius indicated by arrow, without (or little) scaling or is covered by white scales.
25-26, 31-32), from which it differs by the following characters: $a$ ) larger hyaline patches; $b$ ) transparent patches (translucent in L. japola and $L$. genius); c) presence of two large blue antemarginal spots in the dorsal hindwing tornus (lacking in L. japola and L. genius). This distinctive character of blue submarginal spots in cell $\mathrm{CuA} 2$ and $\mathrm{CuA} 1$ is also found in male $L$. decorata Lathy, 1926, an Andean species (Figs. 29-30). L. decorata is a larger, white-banded taxon whose blue spots are lighter, shining blue compared to the dark blue spots of the new species. Another taxon in this group with whitescaled hyaline bands is the Andean L. nicetus (C. Felder \& R. Felder, 1865) (Figs. 27-28); a suite of wing pattern characters easily distinguish this species from $L$. ayawi. The Andean $L$. draudti Lathy, 1932, L. occidentalis K. Johnson \& Salazar, 2004 and an undescribed species from Bolivia are similar to L. nicetus.

In overall wing pattern, L. ayawi females are most similar to L. japola females, their ventral surfaces correlating very closely (Figs. 3-4; D'Abrera 1995: p. 1209, male T. (? L.) japola is female $L$. japola). Besides some subtle ventral pattern differences, most notable is the greater extent of orange scaling conjoined with the hindwing tornal black spot in cell $\mathrm{CuA} 1$ for L. ayawi. Their dorsal surfaces have significant differences. L. ayawi, as compared to L. japola: a) dark brown ground color versus lighter brown, b) structural blue color on the forewing restricted to the region below the cubital vein versus more extensive, $c$ ) dark blue structural color on the hindwing versus lighter silvery blue. A few of the L. ayawi female specimens have a very similar wing shape compared to L. japola females, therefore wing shape would not be a good character to differentiate them. Female $L$. genius have substantial dorsal and ventral wing pattern differences with $L$. ayawi (Figs. 3-4; D'Abrera 1995: p. 1209, female T. (?L.) teatea Hewitson, 1868, is female L. genius). For comparison, outside the „L. genius group”, the females of the sister taxa L. collucia (Hewitson, 1877) and L. orcidia (Hewitson, 1874) have similar dorsal patterns with $L$. ayawi: dark brown ground color; the structural blue color on the 

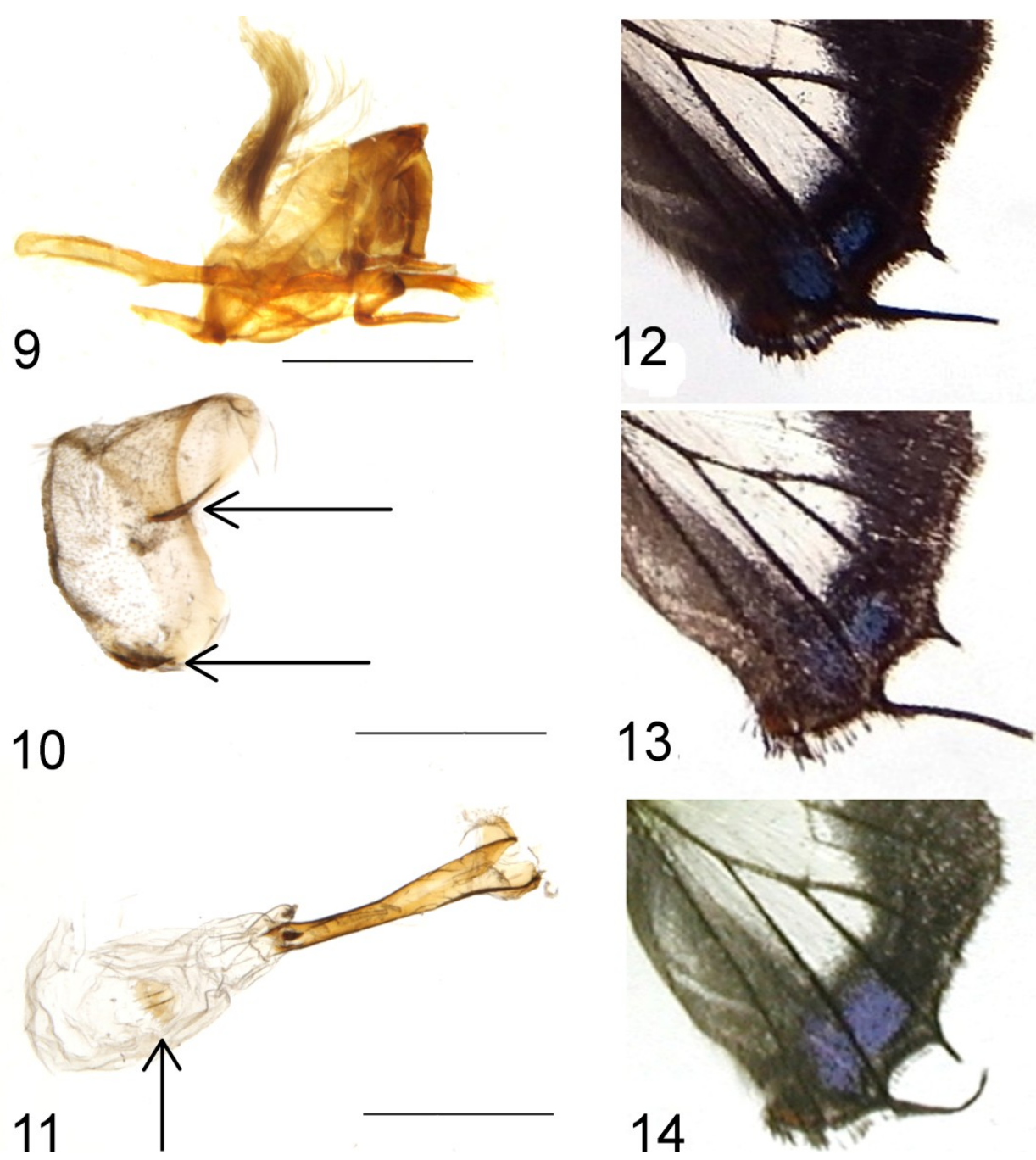

Figures 9-11. Lamprospilus ayawi sp. nov. adult anatomy. $9=$ male genitalia capsula in lateral view (scale bar: $2.2 \mathrm{~mm}$ ); $10=\mathrm{fe}-$ male $8^{\text {th }}$ abdominal tergite with inwardly curved posterior sclerotization indicated by arrow (scale bar: $2.0 \mathrm{~mm}$ ); $11=$ female genitalia ductus and bursa with a pair of fan-shaped signa indicated by arrow (scale bar: 2.2. $\mathrm{mm}$ ).

Figures 12-14. Variation of Lamprospilus ayawi sp. nov. male hindwing submarginal blue spots. 12 = holotype male from Auyán Tepui; 13 = paratype male from Auyán Tepui, 14 = paratype male from Acarai Mountains.

forewing restricted (or nearly so) below the cubital vein; extent of the structural blue color on the hindwing (Figs. 3, 43, 45). The hindwing structural blue color on L. ayawi is substantially darker and there are significant ventral pattern differences between $L$. ayawi and these two species (Figs. 4, 44, 46).

Description. Male. Body: frontoclypeus with erecting black hairs, labial palp black and extremely short, eyes brown, large and hairy, par- ocular area and scape brown, antenna with 17 segments, tip reddish brown, thorax and abdomen black dorsally, abdomen grey ventrally.

Wings. Forewing costal length measured from wing base to apex 12,15 and $15 \mathrm{~mm}(\mathrm{n}=3)$; hindwing with short filamentous black tail with white tip at vein $\mathrm{CuA} 1$ terminus, and with a longer tail at vein $\mathrm{CuA} 2$ terminus; dorsal wing surface translucent with $2-3 \mathrm{~mm}$ wide black costal and outer marginal band, submarginal area in cell $\mathrm{CuA} 1$ with smaller and cell $\mathrm{CuA} 2$ with larger 
highly reflective dark blue spot, hindwing tornus with small reddish scaled lobe; area of anal veins greyish covered by long hairs; fringes black in both wings; forewing ventral surface as in dorsum but coloration lighter brown and with additional patterns: a brownish white line running perpendicular to costa at $2 / 3$ costal length to the middle of vein M1, plus a lighter brown narrow submarginal band running from apex to tornus parallel to outer margin, basally having a narrower short line in the subapical area to vein M1; hindwing ventral surface having area of anal veins with white postmedian and submedian lines (remnants of the familiar eumaeine W-pattern): postmedian one with basal black border, submarginal one with distal black border; large submarginal black spot in cell $\mathrm{CuA} 1$ bordered basally with orange scaling, tornus black, blue scaling between submarginal spot in cell $\mathrm{CuA} 1$ and black tornus; in both wings outer margin with fine white border line, fringes black (Figs 1-2).

Genitalia. Brush organ present with densely arranged hairs, anterior base in lateral view situated on dorsal half of capsule, uncus width in lateral view two times less than height, uncus in dorsal view without posterior process; gnathos base at ventral edge membranous, longer than wide in lateral view, medium-sized tooth based on the basal half of gnathos, tip apiculate and as large as the medial tooth; ventral anterior end of vinculum strut situated on the ventral half of the capsule, saccus putty-knife shaped in dorso-ventral view, valva in lateral view with unequal triangle shape, base long resulting in a continuously tapering shape from the middle posteriorly, aedeagus almost three times as long as valval length with a single cornutus in lateral view upwardly bent (Fig. 9).

Female. Body as in male.

Wings. Forewing costal length measured from wing base to apex $13 \mathrm{~mm}(\mathrm{n}=2)$; wing shape with distal margins more rounded than for male (especially on the forewing); dorsal ground color dark brown, forewing light blue area below the cubital vein, hindwing substantial blue area, mostly on anal margin half, dark blue distally; tornal lobe reddish scaled, area of anal veins grey- ish covered by long hairs; forewing ventral surfaces with warm brown ground color and commonplace eumaeine pattern: forewing with a single postmedian transverse line with dark basal scaling running from costa to cubitus, submargin with a darker brown line scaled lighter basal and running parallel with outer margin from subapical region to tornus; hindwing with the typical "W" shaped medial-postmedial hairstreak pattern, marginal regions as in male but with smaller black spot in cell CuAl and more extended orange scaling, also orange scaling distal to the postmedian line in cell M3 (Figs. 3-4). Abdominal $8^{\text {th }}$ tergum with curved sclerotization at distal end (Fig. 10).

Genitalia. Typical of Lamprospilus (cf. Robbins \& Duarte 2010) with simple slightly sclerotized duct and bursa with length equal to that of the duct, ornamented by a pair of "fan-shaped" signa (Fig. 11).

Variations. The specimens examined show little variation in color and pattern. The six Auyán Tepui males are all extremely similar. The only notable differences between these males and the Acarai specimen are: the size of the tornal upper dark blue spot (possibly also hue of these spots) on the dorsum and the amount of orange scaling basal to the ventral large black tornal spot in cell CuA1. The upper blue spot on the Acarai specimen is substantially larger (Figs. 12-14). The Pantepui specimens have more extensive orange scaling. Whether these differences are consistent and constitute geographic differences between populations from the Pantepui and the Guianan southern mountains will hopefully be ascertained when more specimens are collected.

The females from the two different tepuis, Auyán and Sororopán, showed slight wing pattern variation on the ventral hindwing. The Auyán females have orange distal to the white postmedian band in cell M3 that is lacking in the Sororopán females, also the black spot in cell CuA1 on the Sororopán females is smaller. There is also slight but noticeable wing shape differences between the five females, most conspicuous between the Auyán and Sororopán females. 


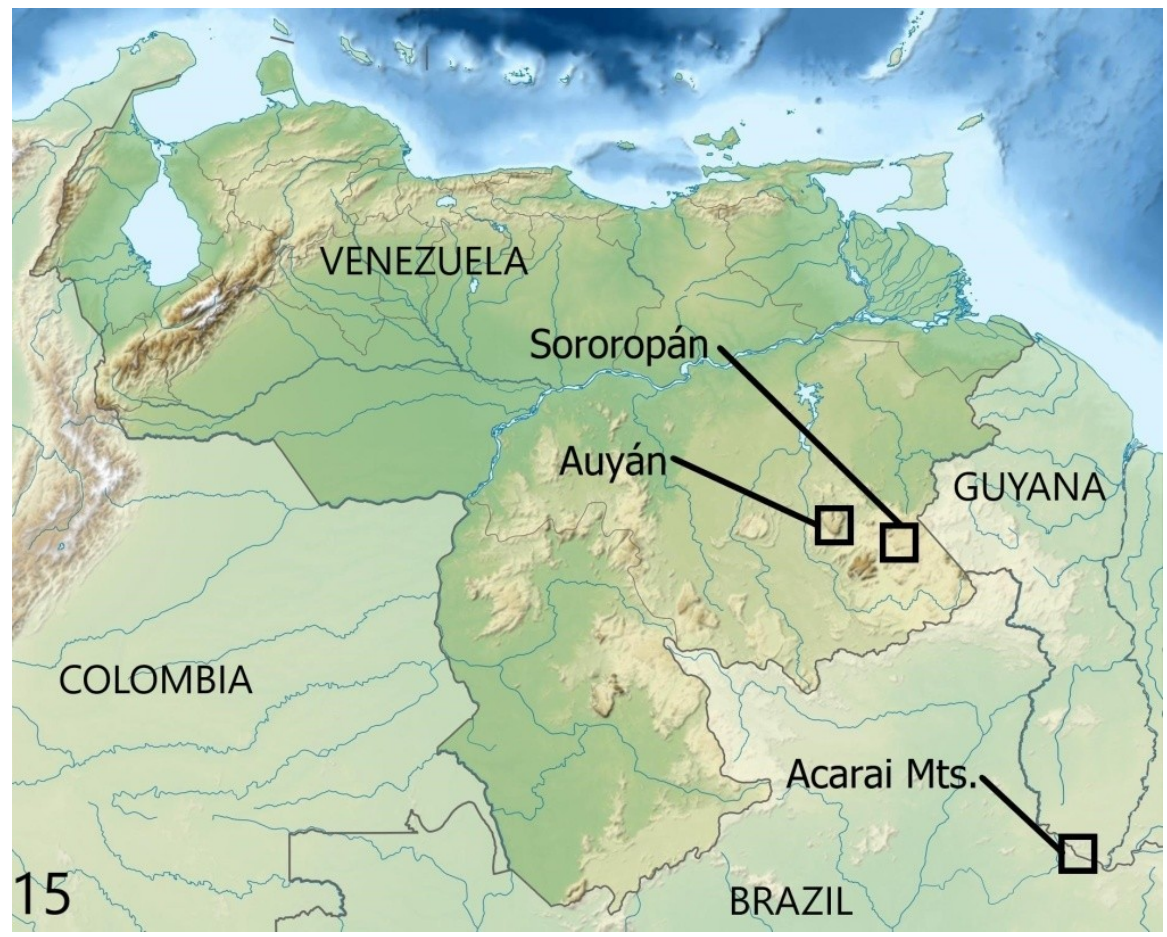

Figure 15. Known localities of Lamprospilus ayawi sp. nov.

Distribution. L. ayawi is presently known from three localities: Auyán Tepui and Sororopán Tepui in Venezuela and the Acarai Mts, astride southernmost Guyana and adjacent Brazil (Fig. $15)$.

Bionomics. The Acarai male was collected at the edge of a large tree fall light gap on a high forested ridge at approximately $925 \mathrm{~m}$ (Fig. 16); this occurred in mid-afternoon, on what was a mostly sunny day. It was perched at approximately $5 \mathrm{~m}$ above the ground, the forest in this area estimated to have a canopy over $20 \mathrm{~m}$ high. This collecting site was an incredible spot for riodinids, a number of Symmachia Hübner, [1819] and Argyrogrammana Strand, 1932 were captured, and other taxa as well. The stunning Symmachia miron Grose-Smith, 1898 with its translucent wing patches was amongst them. One of the two known males of an undescribed Mesosemia Hübner, [1819] (known presently only from the Acarai Mts.) was also collected in this light gap.

The first two of the six Auyán Tepui males were collected (January, 2017) on a slope at 1,500 $\mathrm{m}$ (Figs. 17-18). They also perched at $4-5 \mathrm{~m}$ and had been seen flying straight and fast before landing, coming from elsewhere on the slope. Both perched in a near horizontal position after landing. They were caught on two consecutive days at the same spot and approximate time, late morning, both days mostly cloudy with little sunshine. The third consecutive day, another male was seen on the crown of the same tree $(6-7 \mathrm{~m}$ high) but was not collected. The uppermost portion of this tree's crown was in flower, these blossoms attractive to a number of Lycaenidae, Riodinidae and small moths.

The other four Auyán males were collected two years later in a light gap of a densely forested slope at $1400 \mathrm{~m}$ (at a distance of about one $\mathrm{km}$ from the site of the first two) (Figs. 17-18). They flew very fast and often perched momentarily before taking wing again. Similar to the locality of the Acarai male was the presence of several riodinids (mainly Symmachia and Argyrogrammana) and also Hesperiidae.

The three Auyán females were found on a slope at a higher elevation (1850m) (Figs. 17-18), feeding 

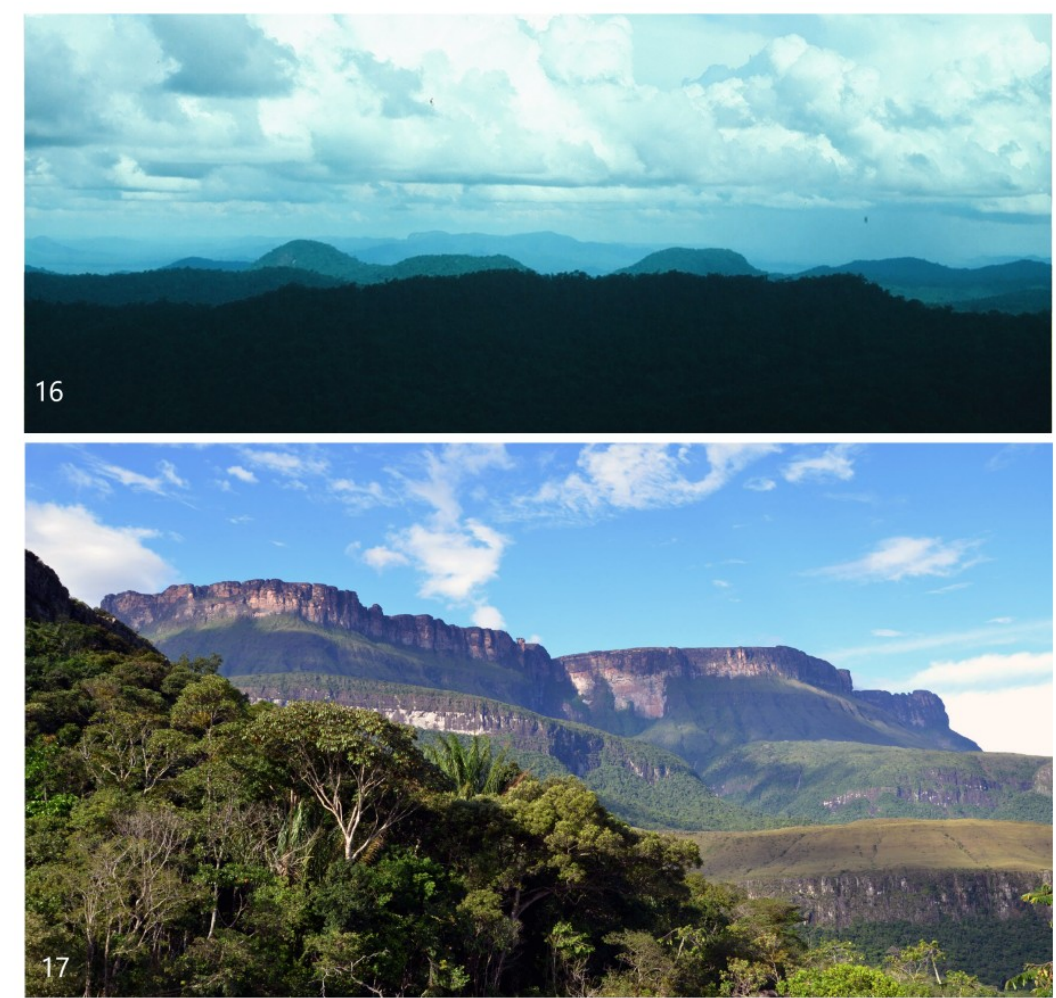

Figures 16 -17. Lamprospilus ayawi sp. nov. habitats in Guyana/Brazil border region and Venezuela. $16=$ Looking east (at approximately $925 \mathrm{~m}$ ), as seemingly 'endless' ridges of the Acarai Mts. (Guyana/Brazil border region) stretch to the horizon. $L$. ayawi sp. nov. was captured in the transition from lowland hill forest to lower premontane forest at this elevation, not too far distant from where this photo was taken. 17 = Premontane rain forest $(1000 \mathrm{~m})$ with the southern slopes and cliffs of Auyán Tepui (Venezuela) rising high above.
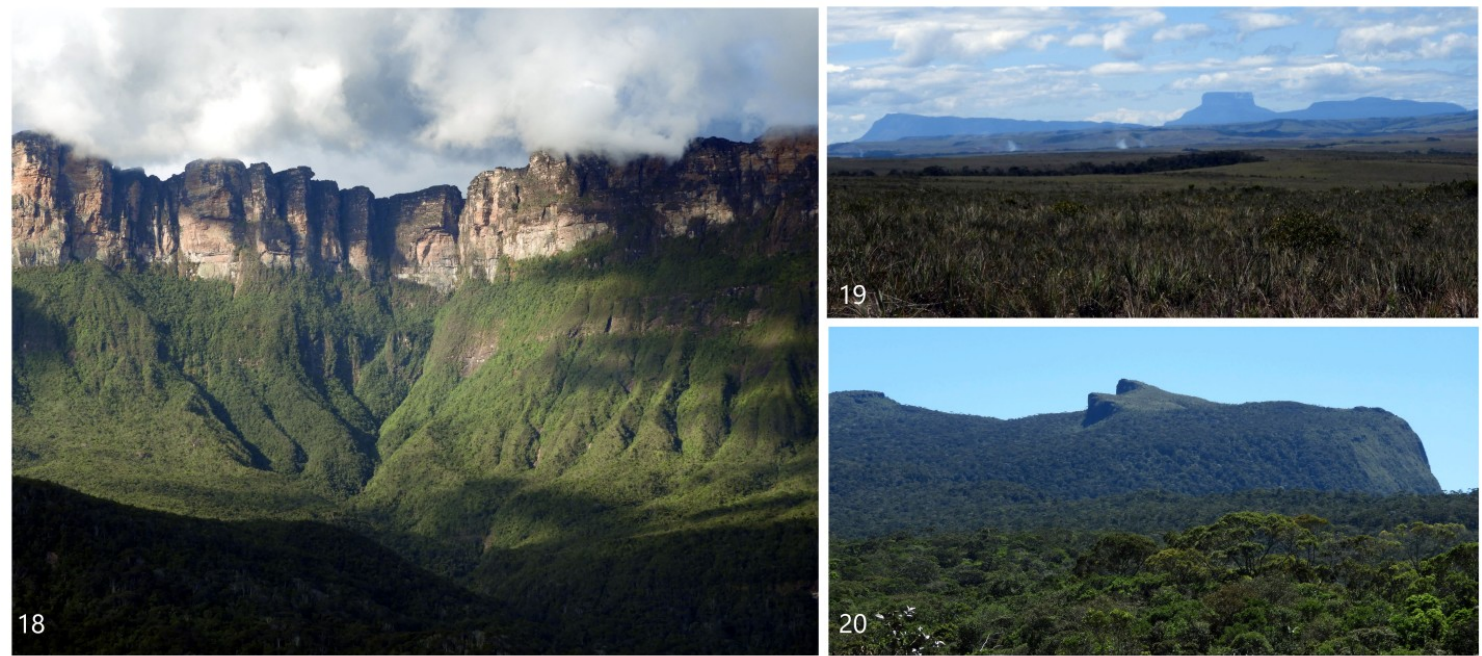

Figures 18-20. Lamprospilus ayawi sp. nov. habitats in Venezuela. $18=$ Looking north from premontane forest at $1000 \mathrm{~m}$ with the great escarpment of Auyán Tepui beyond (2200-2450 m). L. ayawi n.sp. was collected in the intermediate slopes between 1400 and $1850 \mathrm{~m} .19=$ Upland savannah at $1400 \mathrm{~m}$, looking north to the Ptari Massif in the distance: Sororopán Tepui (2050 m) on the left, Ptarí Tepui $(2400 \mathrm{~m})$ in the center and Carrao Tepui $(2200 \mathrm{~m})$ on the right. $20=$ Looking south over premontane slope forest at $1400 \mathrm{~m}$ on Sororopán Tepui; midway from this point and the summit $(2050 \mathrm{~m})$, the first two female specimens of $L$. ayawi sp. nov. were collected at $1650 \mathrm{~m}$. 
on small yellow flowers of an unidentified plant, with dense shrubs the predominant vegetation $(2$ to $5 / 6 \mathrm{~m}$ ); these flowers were also visited by Catasticta duida Brown, 1932, Pirascca hanneri Gallard et al., 2017, Ocaria elisa Bálint \& Costa, 2012 and other unidentified Lycaenidae, Hesperiidae and Erateinae.

The two Sororopán females were collected in upper premontane forest at 1650m (Figs. 19-20), though annotations on behavior were not recorded.

Type locality. Venezuela, Bolívar, Auyán Tepui, El Danto, $1500 \mathrm{~m}, 05^{\circ} 43^{\prime} 50^{\prime \prime} \mathrm{N}, 62^{\circ} 32^{\prime}$ $27 " \mathrm{~W}$.

Etymology. This spectacular unique eumaeine hairstreak is named in honor of Sayra Ayaw, who collected the first specimen in the Acarai Mountains. Sayra, an Amerindian living at Gunns Village, not only caught this beauty, his excellent effort in many facets was indispensable in making the Acarai Mts. expedition such a successful endeavor.

\section{DISCUSSION}

\section{Characters of Lamprospilus and the Lamprospilus genius species-group}

Duarte \& Robbins (2010) presented the following distinguishing characters for Lamprospilus: (1) „one medium-sized tooth in the middle of the male genitalia gnathos”, (2) ,a dark brown patch at the base of the ventral hindwing in males only", (3) „ventral forewing with a dark postmedian band in males only" and (4) female $8^{\text {th }}$ abdominal tergite with an inwardly curved posterior sclerotization.

Character 1 is not stable, as it was remarked that it is poorly developed or even absent in Lamprospilus coelicolor (A. Butler \& H. Druce, 1872) (Robbins \& Duarte 2010). This is not a unique phenomenon in the genus, as we could not detect this gnathos tooth in an undescribed Lamprospilus collected in Bolivia. However, in L. ayawi it is evident and confirms its placement in the genus.
Character 2 is present in all Lamprospilus taxa examined by the authors. It is very prominent in $L$. genius and $L$. aunus, the two taxa figured in $\mathrm{Du}-$ arte \& Robbins (2010) (Figs. 22, 26). It is easily discerned but sometimes less conspicuous in other taxa (Figs. 2, 24, 28, 30, 32, 34, 36, also D'Abrera 1995: p. 1099 for a less worn specimen of $L$. nicetus). We did not have access to specimens or good quality images of $L$. draudti and $L$. occidentalis to check for this character. Character 3 is not a valid character for all Lamprospilus, actually less than half of the described taxa possess it. This trait is also very conspicuous in the two species illustrated in Duarte \& Robbins (2010) but this dark band/patch is medial rather than postmedian. It is also prominent on L. coelicolor (Fig. 24) and on L. japola (Fig. 32); L. decorata, L. ayawi, L. collucia and $L$. orcidia all lack this character. In $L$. decorata, the medial area possesses the same brown coloration that is the ground color for the greater portion of the forewing (Fig. 30). For $L$. ayawi (which though undescribed, was known by at least one of these authors), a good portion of the medial area is part of the large transparent patch. L. ayawi manifests a costal dark patch from the wing base to approximately two thirds out along the costal margin (Fig. 2). A medial dark band/patch is obviously absent in both $L$. collucia and L. orcidia (Figs. 34, 36). This character is ambiguous for $L$. nicetus and closely related taxa: $L$. draudti, L. occidentalis and an undescribed species from Bolivia. In all these taxa, there are significant portions of the forewing, both distal and basal to the medial area, which are as dark as the medial area (D'Abrera 1995: p. 1099). Character 4 also confirms the placement in Lamprospilus but more investigation is needed to evaluate the variability of this trait; lacking adequate material, we cannot explore this further at this time.

Duarte \& Robbins (2010) mentioned that "Lamprospilus was traditionally restricted to males that had white or hyaline longitudinal bands across the dorsal and ventral wings (Lathy 1932; D'Abrera 1995), a monophyletic grouping after one species with white bands in both sexes (Thecla azaria Hewitson, 1867) was moved to another section of the Eumaeini (Robbins 2004)." This group of species, Lamprospilus in a strict 

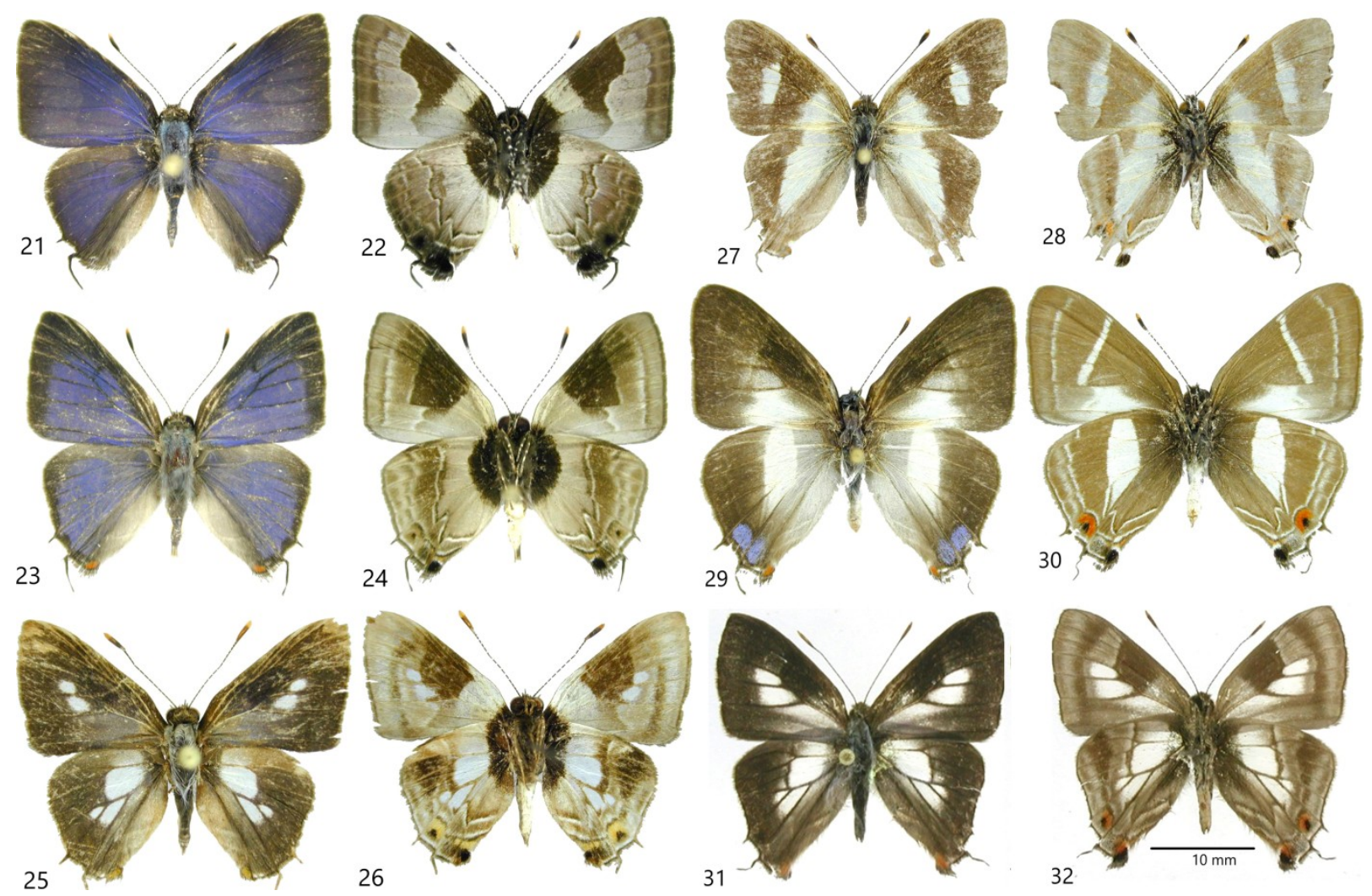

Figures 21-32. Male Lamprospilus imagines. $21=$ L. aunus, French Guyana, recto; $22=$ idem, verso; $23=$ L. ("Gigantorubra") coelicolor; French Guyana, recto; $24=$ idem, verso; $25=$ L. genius, recto; $26=\mathrm{idem}$, verso; $27=$ L. nicetus, Venezuela, recto; 28 = idem, verso; $29=$ L. decorata, Peru, recto; $30=$ idem, verso; $31=$ L. japola, SE Brazil, recto; $32=$ idem, verso.

sense, constitutes the Lamprospilus genius species group and is represented by several species distributed widely in the more mesic forested areas of the northern half of South America: Amazonia, the Andes, the Atlantic Forest and the Guiana Highlands. All the males can be identified on the basis of wing pattern (see the Diagnosis above) (cf. Figs. 1-2, 25-32).

The hypothetical sister species group of Lamprospilus s. str. (= Lamprospilus genius species group) is the group of taxa presently placed in the genus, which possess dorsally blue or violet colored males. Formally most of the species representing this group were placed in the genus $G i$ gantorubra Johnson, 1993 (type species: Thecla collucia Hewitson, 1877, by original designation) (Johnson 1993, Austin \& Johnson 1997). This genus was synonymized with Lamprospilus by Robbins (2004) and Duarte \& Robbins (2010).
Probably a fine graded approach (Oláh et al., 2018) for this clade would demonstrate that there is evidence to apply the name Lamprospilus in a strict sense to the hyaline and white patterned species and also to use the genus-group name Gigantorubra for the species with structurally colored males (Figs. 21-24, 33-36).

\section{Associating the female phenotype}

Associating sexes of eumaeine lycaenids is difficult. For this quandary, there are good examples in Lamprospilus, as male and female phenotypes were described several times as distinct species because of marked sexual dimorphism (see Robbins 2004, and Warren et al. 2018). A number of taxa illustrated demonstrate the phenomenon of pronounced sexual dimorphism in Lamprospilus (Figs. 23-24, 27-30 and 33-46). Our reasons for associating the male phenotype col- 


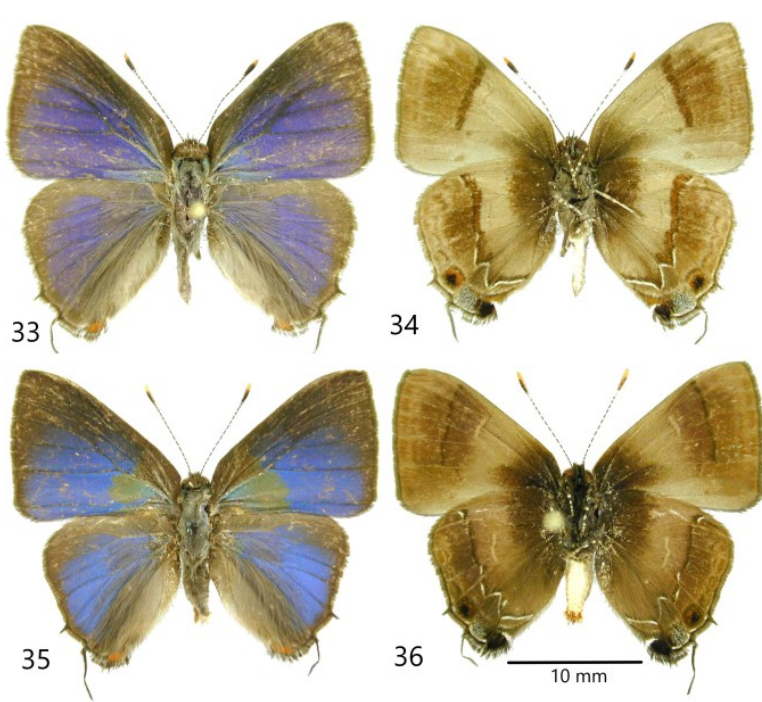

Figures 33-36. Male Lamprospilus ("Gigantorubra") imagines. $33=L$. collucia, Mexico, recto; $34=$ idem, verso; $35=L$. orcidia, Brazil (Amazonas), recto; $36=$ idem, verso.

lected on Auyán Tepui and in the Acarai Mountains with the phenotype represented by five female specimens from Auyán and Sororopán Tepuis are as follows.

The Lamprospilus female phenotypes are not easy to identify even on the generic level. Wing shape and pattern all follow the general groundplan of the tribe: dorsal wing surfaces manifest structural blue coloration; ventral wing surfaces with a white postmedial line, this line often with basal red scaling and forming a W-shaped pattern between veins $\mathrm{M} 3$ and $\mathrm{CuA} 2$ basal to the submarginal Thecla-spot; vein termini $\mathrm{CuA} 1$ and $\mathrm{CuA} 2$ are tailed. Similarly, there is no clear-cut character in the female genitalia, although the $8^{\text {th }}$ tergite is with modification. This is also a subtribal character, the distinctively curved sclerotization at the lateral edge also occurring in other calycopidine genera ( $c f$. Duarte \& Robbins 2010: figs. 16-23). Nevertheless, with the combination of the mentioned characters and comparison with male ventral surfaces, candidate female specimens can be placed in Lamprospilus with great certainty, as the five specimens collected on Auyán and Sororopán Tepuis.

During the one decade long survey in the Pantepui region (cf. Costa et al. 2017) only two males of $L$. coelicolor have been collected : between San Francisco de Yuruaní and Paraitepui, km 7, 1200 $\mathrm{m}, 27$. III.2005 and between Uruyén and Guayaraca, $1000 \mathrm{~m}, 22 . I I I .2013$. (Bálint et al., unpublished). The female of $L$. coelicolor, described as Thecla hena Hewitson, 1874 (cf. D'Abrera 1995: 1206, ventral figure), has a character unique in the genus for female phenotypes: the forewing ventral surface reveals a submedian white line in the discal cell (Fig. 38). Thus the Auyán/ Sororopán specimens cannot represent the female of $L$. coelicolor.

When we consider male phenotypes, the closest species to $L$. ayawi is $L$. japola (Figs. 1-2, 5-6 and 31-32). Accordingly, we suspect that their females should also be similar. And indeed, the female phenotype of $L$. japola is quite similar with the Auyán/Sororopán specimens ( $c f$. D’Abrera 1995: 1209 (labelled as male), (Figs. 34)), but there are two distinctive characters: (1) the dorsal non-iridescent ground color (2) the extent of dorsal structural blue coloration on the forewing and difference in hue on the hindwing. The differences for these two characters are elucidated in the Diagnosis above, but we present here a short discussion on their variability placed in a wider taxonomic scope.

Character (1), when the whole spectrum of female phenotypes is known for a genus, is often helpful for positive identification (for example in hairstreaks representing the genus Penaincisalia K. Johnson, 1990). Character (2) involves structural blue coloration, which is often species specific and stable in the case of the polyommatine lycaenid butterfly males, even under strong environmental pressure (Kertész et al. 2017).

Interestingly, dorsal structural coloration is quite plastic in the case of females, because as experiments demonstrate, cold shock activates genes that produce structural color generating scales (Kertész et al. 2019). It is an interesting topic for further investigation in tropical Lycaenidae, how the wing scaling of different phenotypes would react to various environmental variables. At the moment, no experimental data is available on how structural color relates comparatively in females and how variable it is, but we suspect that it also has an important sexual role. 


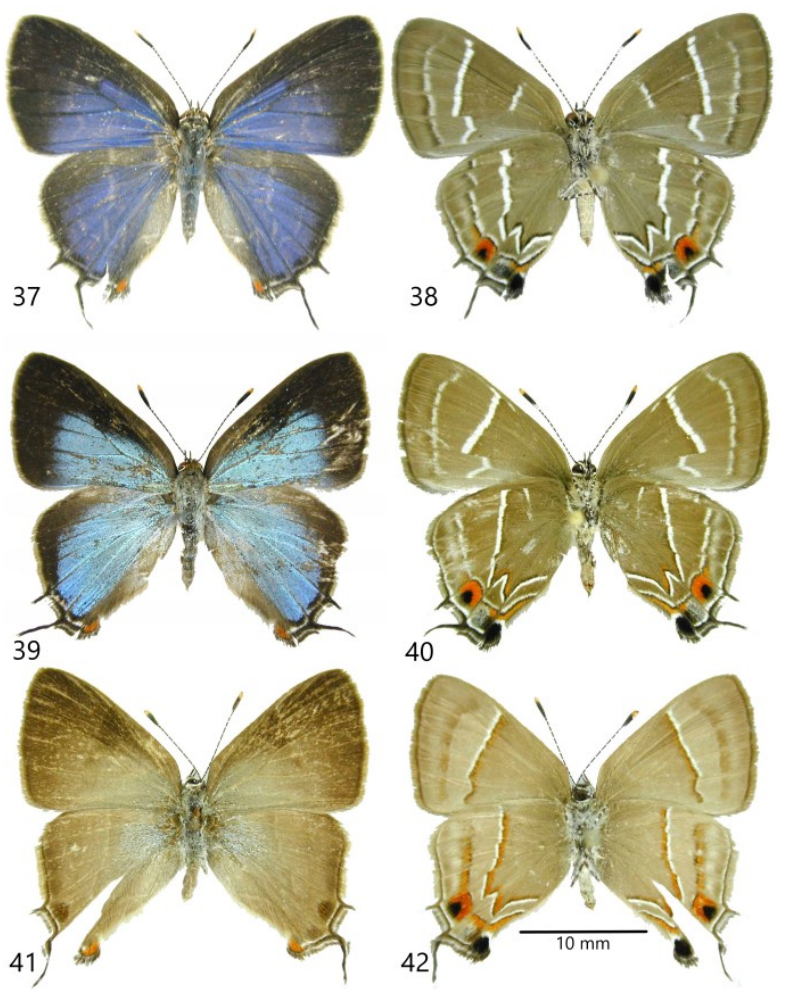

Figures 37-42. Female Lamprospilus imagines. $37=L$. (“ $G i$ gantorubra") coelicolor, Ecuador, recto; 38 = idem, verso; $39=L$. decorata, Ecuador, recto; $40=$ idem, verso; $41=L$. nicetus, Venezuela, recto; $42=$ idem, verso.
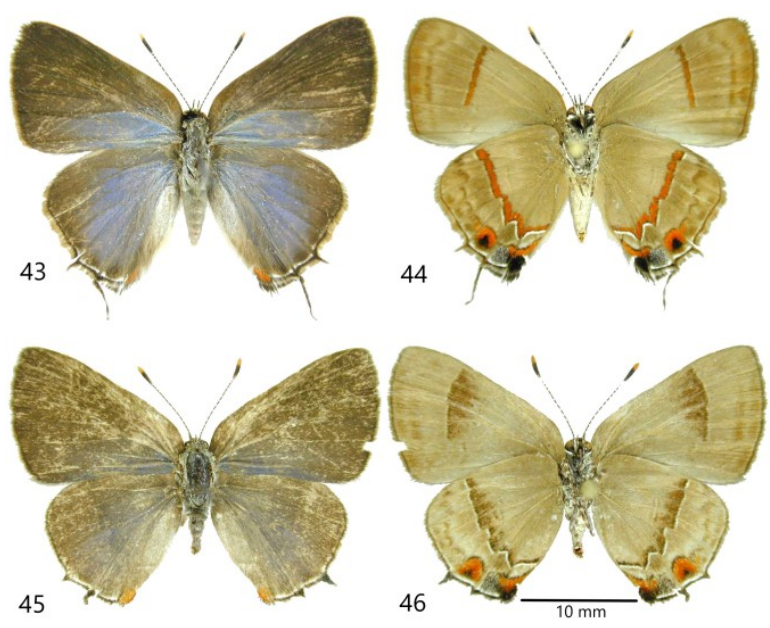

Figures 43-46. Female Lamprospilus ("Gigantorubra") imagines. $43=L$. collucia, Mexico, recto; $44=$ idem, verso; $45=$ L. orcidia, Ecuador, recto; $46=$ idem, verso.
As noted above, the wing shapes of a few of the $L$. ayawi females are very similar to that of $L$. japola females. Although wing shape will probably not be a reliable character to separate these two taxa, we remark that wing shape in eumaeines is often a good character; for example distinguishing Johnsonita Salazar \& Constantino, 1995 and Salazaria D’Abrera \& Bálint, 2001 (Bálint in prep.), or the several species groups (or genera) of Penaincisalia (cf. Bálint \& Wojtusiak 2006).

In summary: regarding female wing facies, $L$. ayawi has the closest resemblance to L. japola, with dorsal differences stated above and the two taxa sharing quite similar ventral patterns. Other hyaline patterned Lamprospilus species have corresponding females with distinctive phenotypes, their intensive ventral wing surface patterns ornamented with white (L. genius) or orange ( $L$. nicetus) (Fig. 42) scaling. Therefore we are very confident in our association of the two phenotypes for L. ayawi.

\section{The male phenotype}

It seems that male eumaeine dorsal coloration is also species specific in tropical ecosystems ( $c f$. Bálint et al. 2008 and 2009), and amongst them the phenomenon of discoloration (Biró et al. 2003) also occurs (Bálint 2004). In Lamprospilus, only $L$. aunus and L. coelicolor, plus $L$. collucia and $L$. orcidia species pairs, have structurally blue colored males. The male of $L$. genius possesses both structural blue color on the forewing and hyaline patches. It intermediates the structurally blue colored species, and the hyaline and white banded species, that according to Duarte \& Robbins (2010, fig. 61), constitute the sister group of the blue species. The undescribed species from Bolivia seems to be the only species in the genus having a male phenotype in the discolored state.

It is generally assumed that the myriad bright colors and/or distinctive patterns that adorn the dorsal surfaces of the world's diurnal Lepidoptera are predominantly for communication: in the great 
majority for sexual attraction and territorial display; to a much lesser degree but still numerous, for aposematic display. The vast majority of the multitudinous Neotropical eumaeines manifest various hues of brilliant blue/purple structural color dorsally, often covering a good portion of this surface, more prevalent in males and also often more pronounced in this sex. Taking into account the high diversity of taxa that occurs together in many habitats throughout the Neotropical region, especially in lowland and premontane rainforests but still diverse in montane and upper montane forests and even in high altitude puna and paramo regions, it follows logically that the various hues, as well as the patterns of structural color, would be for mate selection. Field experience with these dazzling jewels poses interesting questions concerning eumaeine communication.

In thousands of days exploring Neotropical rainforests, in the lowlands and montane regions: Central America, the Guiana Highlands and the Andes, not one eumaeine was seen perching with its wings open from the thousands that were observed (all authors, pers. obs.). This includes a small number observed in upper forest levels including the canopy. Though upper forest levels might be a major microhabitat for Neotropical eumaeines and observation there was minimal, the overall data strongly suggests that these hairstreaks, including Lamprospilus, predominantly perch with their wings closed. All of them fly rapidly and erratically, could visual signals for mate selection be given in flight with only small interval bursts of color and certainly almost no way to discern pattern at this speed by human eyes? However, experiment based evidence suggests that the optical systems of diurnal Lepidoptera are able to detect and distinguish these four dimensional species specific signals, and females prefer the brightest individuals (Kemp 2007, Imafuku \& Kitamura 2018). Considering this evidence, the question arises: why do so many eumaeine males possess androconia, olfactory communication possibly being paramount for mate selection?

Lamprospilus manifests a number of very distinctive phenotypes, various aspects of this discussed previously. The taxa with blue structurally colored males, though possessing aberrant 'banded' undersides, have dorsal blue uppersides that place them in the realm of the majority of Neotropical eumaeines, though they and other Lamprospilus lack androconia.

Though there are some eumaeines that in both sexes or only the females are predominantly dorsally white [e.g. Arawacus Kaye, 1904 sp.; Laothus K. Johnson, Kruse \& Kroenlein, 1997 sp.; Rekoa meton (Cramer, 1779); Brangas neildonatus Bálint \& Faynel, 2008 (Bálint, unpublished); and also female L. draudti (Bravo et al. 2009)], taxa dorsally banded with white/white-scaled hyaline is restricted to male Lamprospilus: $L$. decorata, L. nicetus and allies, and also Thestius azaria (Hewitson, 1867). Wing surfaces of white diurnal Lepidoptera, or on a smaller scale, banded with white, reflect a much wider spectrum of the available light because of their nanomorphology (Luke et al. 2009). This would constitute a quite different signal than the blue/ purple species whose reflectivity would be in a much narrower zone of the visible spectrum. Could this result in a communicative advantage for these Lamprospilus in various microhabitats of the Andean forests that they inhabit?

Another similarly plausible explanation and related to the previous one, is that in forest light islands where there are high a aggregation of patrolling eumaeine species, present in the same habitat not only in time and space but also similar in the manner how the great majority of male dorsal wing surfaces produce signals, having a different way to communicate could be advantageous ( $c f$. Robbins \& Busby 2009). It was recorded for example, that in one Colombian eumaeine community, blue and white-banded Lamprospilus species shared the same habitat niche (Prieto and Dahners 2006, 2009). Was this facilitated by their different ways of communicating? We note that a few members of the riodinid genus Siseme Westwood, 1851 (and to a lesser degree the riodinid genus Anteros Hübner, [1819]) have a similarity in general wing pattern to these white-banded Lamprospilus. We 
lack the empirical experience to know if they coexist in the same Andean forests and will not conjecture on whether this resemblance bears any significance. Further evaluation in the field is required.

Also very distinctive among eumaeines are the male hyaline patched $L$. genius, $L$. japola and $L$. ayawi. The relatively widely distributed $L$. genius has smaller hyaline patches than L. japola, substantially smaller compared to L. ayawi. What the function is for individual elements or the dorsal pattern in totality for this exquisite 'intermediate' Lamprospilus is an interesting enigma. A plausible explanation for the small fenestrated patches that adorn the wings of $L$. genius is that this represents an example of protective resemblance camouflage involving water droplets. This phenomenon also occurs in a number of saturniid taxa and will be discussed further below. L. japola and L. ayawi, as in L. nicetus, have significant areas of their wings hyaline. Fenestrated wing areas are unique to Lamprospilus among the world's lycaenids. L. ayawi, which has the largest percentage of its wing area hyaline, is unique in that these areas are truly transparent, not translucent as in other taxa.

Transparency/translucency reaches its zenith in the Neotropics, both in total diversity and that all butterfly families have members with this quality, this phenomenon being much more restricted in the Afrotropical, Oriental and Australian regions. This can partly be explained by: the overall great diversity of the Neotropical butterfly fauna; the speciose ithomiines, the dominant hyaline butterfly group, with numerous transparent/translucent species (among others); and the presence of mimicry rings with these ithomiines presumably as models, in which occur all or most of the hyaline species of other butterfly families (e.g., papilionids, dismorphiine pierids, riodinids). Seeing transparent-winged ithomiines flitting through the dark understory of a lowland tropical understory or Cithaerias Hübner, [1819] and Haetera Fabricius, 1807 (haeterine satyrines) flying ghost-like just above the forest floor in these same forests, leaves little doubt that camou- flage by transparency is in effect (all authors, pers. obs., Siddique et al. 2015). Obviously, when these and other hyaline-winged butterflies are resting in the dark forest interior, camouflage by transparency would be a very effective protection mechanism. When $L$. ayawi was first discussed (Fratello 2005), it was speculated that its large transparent wing patches might render it less visible when at rest, again camouflage by transparency. This might not be the case at all and herein are given other possible explanations.

As mentioned above for L. genius, the hyaline patches of $L$. japola and $L$. ayawi might also be examples of protective resemblance camouflage involving water droplets. What could make this an effective deception is the way in which many eumaeines perch. When perching, usually on the upper surface of leaves, they often angle their closed wings closer to a horizontal rather than vertical position (all authors, pers. obs.; $c f$. Hoskins \& Bálint 2016). It is conjectured that this manner of perching is for defensive purposes in regards to sharp-eyed predators (e.g. birds): they are less obtrusive from the leaf surface and also their shadows are minimized. In fact, the Auyán males were recorded perching in this manner (the manner in which the Acarai Mts. male was perched was not observed). Could the larger transparent patches of L. ayawi (and larger translucent patches of L. japola as well) serve to function for a different purpose? Dushkina et al. (2017) stated that the hyaline wing surface has practically no reflectivity. Siddique et al. (2015) stated, following experimental results, that the ithomiine Greta oto (= Greta morgane oto (Hewitson, [1855]), (Lamas 2004) has "transparent wings with remarkable low haze and reflectance over the whole visible spectral range even for large view angles of $80^{\circ}$." Is there the possibility that if $L$. ayawi males were perched as stated above, that incident sunlight at a certain angle range could be reflected effectively enough from its transparent patches to be a signal for females? Empirical evidence (MC \& $\mathrm{MB}$, pers. ob.) from the latest expedition to Auyán Tepui (2019) might shed some light on this last hypothesis. SF (2005) hypothesized that while flying, the small size and 
rapid flight of this hairstreak would render the transparency of its wing patches not observable to human eyes. That this was verified by recent observations is not surprising. What is surprising is that both in flight and at rest (5-6 meters distant), L. ayawi appeared as a small brilliant white butterfly with black borders. Even at rest at this relatively close distance, transparency was not observed. In flight caused by the rapid wing beats or at rest with the two wing membranes acting like a mirror, microstructures could be causing the scattering of light randomly and intensely, with the resultant brilliant white color. Future field observation in its remote Guiana Highlands home and experiments in the lab, will hopefully give deeper insight into the function of the enigmatic large transparent wing patches possessed by a small lycaenid.

\section{Distribution and endemism}

Auyán Tepui and Sororopán Tepui are proximate to each other (nearly $90 \mathrm{~km}$ ) (Fig. 15). How extensively $L$. ayawi ranges in the Pantepui will hopefully be discovered in the future. Though a fair number of tepuis have been explored for Lepidoptera (Fratello 2004, Costa et al. 2014a, 2014b, 2016, 2017, 2018, 2019), still many remained totally unexplored for this group. Also considering the vicissitudes of weather, often inclement in these misty highlands, the unknown phenology of these montane taxa, and other variables, a few weeks on a single tepui will hardly reveal the extent of its butterfly diversity. However, considering that $L$. ayawi is also present on Sororopán Tepui, one of the tepuis that rise from the extensive Gran Sabana plateau (about 10,800 $\mathrm{km}^{2}$ ), we surmise that this species probably inhabits the slopes of other tepuis of the Gran Sabana. It is remarkable that $L$. ayawi has never been reported from the intermediate levels of the Gran Sabana plateau (900-1200 m), despite this elevational zone having been sampled much more extensively than the higher tepui slopes (Figs. 1720).

Besides the Acarai Mts., four other ranges in southern Guyana: Iwokrama Mts., Kanuku Mts.,
Kamoa Mts. and Wassarai Mts., possess high ridges/peaks at an elevation equal to or higher than the elevation (approximately $925 \mathrm{~m}$ ) at which the Acarai Mts. L. ayawi was collected. The Kamoa and Wassarai Mts. remained unexplored for Lepidoptera. A total of a few weeks' time has been spent exploring for Lepidoptera on the high ridges/peaks of just small portions of the Iwokrama and more extensive Kanuku Mts. As in the Pantepui, much more exploration is needed to ascertain the butterfly diversity of all these ranges and whether L. ayawi inhabits them. The Acarai Mts. are the western and highest part of a continuous upland area that forms the border between Guyana, Suriname and French Guiana to the north, and Brazil to the south; rivers to the south of these mountains drain to the Amazon, rivers to the north have an Atlantic drainage. Further exploration of these mountains that are lower than the Acarai, e.g. the Tumuc Humac Mts. bordering French Guiana/Surinam and Brazil, will hopefully ascertain whether $L$. ayawi dwells below the lower premontane zone.

The only other mountains in the Guiana Highlands to attain $925 \mathrm{~m}$ are central Suriname's Wilhelmina Mts. which include: Tafelberg (1026 $\mathrm{m})$, the easternmost tepui and Julianatop (1280 m), the highest peak in the Guiana Highlands outside the Guiana Highlands proper. To our knowledge, their heights are unexplored for Lepidoptera but could possibly harbour populations of what seems to be a taxon endemic to the premontane forests of the Guiana Highlands.

With 12 specimens collected within the elevational range of approx. 925-1,850 $\mathrm{m}$ and none collected in extensive exploration of Amazonian lowlands, we presume $L$. ayawi to be endemic to premontane forest of the Guiana Highlands. As the Pantepui region has by far, much more extensive premontane forest than other mountainous areas in the Guiana Highlands, and no other mountains in the Guiana Highlands come close to $1,850 \mathrm{~m}$ elevation, present evidence strongly suggests that $L$. ayawi is primarily a Pantepui species. It is noteworthy to mention that this is the first and only butterfly taxon known to us that 
seems to be a premontane species and is found in both the Pantepui and Guianan southern mountains. Present evidence (SF, unpublished data) suggests that the Pantepui and Guiana southern mountains have significantly different butterfly faunas at the lower premontane level. Future exploration might ascertain a stronger correlation between the lower premontane butterfly faunas of these two subregions of the Guiana Highlands. If the Guianan southern mountains (including Surinam's Wilhelmina Mts.) contain populations of a number of taxa now considered Pantepui endemics, a refined definition of Pantepui endemic (Costa et al. 2014b) could include all areas of the Guiana Shield above approximately $1,000 \mathrm{~m}$, not solely those areas in the Pantepui sensu stricto.

Acknowledgements - We thank Mr Pierre Boyer for consultation and his extensive Lamprospilus documentation (partly used for figures 21-30, 33-46), and for Mr Gergely Katona in helping with the illustrations. The work is supported by the Hungarian scientific projects OTKA K 111741 and K 115724.

SF thanks a number of people whose support and excellent efforts made the Acarai Mts. expedition such a successful endeavor. This expedition was funded under the auspices of The Biological Diversity of the Guianas program. Botanists Vicki Funk and Carol Kelloff administered this program and provided the opportunity for SF to undertake this and a number of other expeditions to Guyana's remote montane regions. Ephon, an Amerindian from Gunns Village, did a fine job as our boat captain for the day and a half the expedition had a boat engine. Expedition members who excelled in all facets of this long arduous expedition included: head assistant Romeo Williams, University of Guyana; student Keith David and Amerindians Sayra Ayaw and Thomas Andrew, both also from Gunns Village. Their exemplary work included collecting many other scientifically important Lepidoptera specimens, among them additional new/undescribed taxa. Scott Miller, then Director of the Smithsonian Department of Entomology generously allowed staff time and equipment to be used for specimen photos. Patricia Poole, then Museum Specialist, took excellent photos of Lamprospilus and other taxa, a few used in this paper (Figs 5-6 and 31-32).

MC thanks Paolo Costa and Dulce Romero for their help and company in the recent expeditions to the Pantepui; Ricardo, Tito and Martín Chaní (from the Pemón community of Kavanayén, Gran Sabana, Bolívar, Venezuela), Boris and Nicolás Briceño (from the Pemón community of S. Marta and Uruyén, Bolívar, Venezuela) without whose guiding and help it would not have been possible to carry out the expeditions. Finally a special thanks to Vilma Savini (MIZA director), José Clavijo, Jürg DeMarmels and Quintín Arias (MIZA) for their support and collaboration.

\section{REFERENCES}

AUSTIN, G.T. \& JohnsON, K. D. (1997): Theclinae of Rondônia, Brazil: Gigantorubra and Angulopis, with descriptions of new species (Lepidoptera: Lycaenidae). Insecta Mundi, 11(3/4): 255-272, 34 figs.

BÁLINT, Z. (2004): Notes on certain high Andean orange eumaine lycaenids with description of a new species from Peru (Lepidoptera: Lycaenidae: Eumaeini). Annales Musei Historico-Naturalis Hungarici, 96: 261-272.

BÁLINT, Z. (2005): Frederick W. Goodson and his contribution to the taxonomy of Neotropical hairstreak butterflies (Lepidoptera: Lycaenidae: Eumaeini). Systematics and Biodiversity, 2(4): 355373, 13 figs., 1 tab.

BÁLINT, Z. \& GoOdGER, K. (2003): The Neotropical eumaeine lycaenids of the Cajetan and Rudolf Felder collection. Part I: Review of type material of the taxa described by the Felders (Lepidoptera, Lycaenidae). Quadrifina, 6: 67-140, 76 figs.

Bálint, Z., Boyer, P., Kertész, K. \& Biró, L.P. (2008): Observations on the spectral reflectances of certain high Andean Penaincisalia and Thecloxurina, with the description of a new species (Lepidoptera: Lycaenidae: Eumaeini). Journal of Natural History, 42(25-26): 1793-1804. doi: 10.1080/00222930802097675

BÁlint, Z., Moser, A., Kertész, K., Biró, L.P. \& PARKER, A.R. (2009): A supposition: structural colours resulting from both natural and sexual selection on an individual wing in the butterfly genus Cyanophrys (Lepidoptera: Lycaenidae). Annales Historico-Naturales Musei Nationalis Hungarici, 101: 63-79.

BÁLINT, Z. \& WoJTuSIAK, J. (2006): Contributions to the knowledge of Neotropical Lycaenidae: Notes on Thecloxurina with the description of three new species (Lepidoptera: Theclinae: Eumaeini). Genus, 17(4): 585-600, 14 figs.

Biró, L. P., BÁlint, Z., KertésZ, K., VéRtessy, Z., MÁRK, G.I., HORVÁTH, Z.E., BALÁZs, J., MÉHN, D., KIRICSI, I., LOUSSE V. \& Vigneron, J.-P. (2003): Role of photonic-crystal-type structures in the thermal regulation of a Lycaenid butterfly sister species pair. Physical Review, E 67(2 Pt 1):021907 doi: 10.1103/PhysRevE.67.021907 
Bravo, A.V., VÉlez, P.D. \& WolfF EcheVErRI, M.I. (2009): Mariposas del Parque Ecológico Piedras Blancas. Guía de campo. Medellín, Fondo Editorial Comfenalco Antioquia, $201 \mathrm{pp}$.

Costa, M., Viloria, Á.L., Attal, S. \& Orellana, A.M. (2014a): Lepidoptera del Pantepui. Parte II. Descripción de nuevos Nymphalidae (Papilionoidea). Bulletin de la Société Entomologique de France, 119(1): 39-52, 23 figs.

Costa, M., Viloria, Á.L., Huber, O., Attal, S. \& OrellanA, A.M. (2014b): Lepidoptera del Pantepui. Parte I: Endemismo y caracterización biogeográfica. Entomotropica, 28(3) [2013]: 193-217, 5 figs., 1 tab.

Costa, M., Viloria, Á.L., Attal, S., NeIld, A.F.E., FRATEllo S.A. \& NAKAHARA, S. (2016): Lepidoptera del Pantepui. Parte III. Nuevos Nymphalidae Cyrestinae y Satyrinae. Bulletin de la Société Entomologique de France, 121(2): 179-206, 42 figs., 1 tab.

Costa, M., Viloria, Á.L., AtTal S., Neild, A.F.N., Fratello, S.A., Callaghan, C.J. \& Gallard, JY. (2017): Lepidoptera del Pantepui. Parte IV. Nuevos Riodinidae (Riodininae) y Pieridae (Pierinae). Bulletin de la Société Entomologique de France, 122(3): 269-286, 46 figs., 1 tab.

Costa, M., Viloria, Á.L., Attal, S., Benmesbah, M., NeILD, A.F.E. \& BÁlint, Zs. (2018): Lepidoptera from the Pantepui. Part V. New Lycaenidae (Theclinae: Eumaeini). Opuscula Zoologica Budapest, 49(2): 163-179. doi: $\underline{10.18348 / \text { opzool.2018.2.163 }}$

Costa, M., Viloria, Á.L., Attal, S., Orellana, A. \& BeNMESBAH, M. (2019): Lepidoptera del Pantepui. Parte VI. Nuevos Hesperiidae (Hesperiinae) y Nymphalidae (Limenitidinae y Satyrinae). Bulletin de la Société Entomologique de France, 124(1): 77-102, 54 figs., 1 tab.

D'ABRERA, B.L. (1995): Butterflies of the Neotropical Region. Part VII. Lycaenidae. Victoria, Black Rock, Hill House. pp. i-xi, 1098-1270, figs.

DrAUdT, M., (1920): Familie: Lycaenidae. In. SEITZ, A. (Ed.), Die Gross-Schmetterlinge der Erde. Stuttgart, Alfred Kernen. 5: 769-824, pls. 144-159.

DuARTE, M. \& RoBBINS, R.K. (2010): Description and phylogenetic analysis of the Calycopidina (Lepidoptera, Lycaenidae, Theclinae, Eumaeini): a subtribe of detritivores. Revista Brasileira de Entomologia, 54(1): 45-65, 61 figs., 1 tab.

DUSHKInA, M.N., ERTEN, S. \& LAKHTAKIA, A. (2017): Coloration and structure of the wings of Chorinea sylphina Bates. Journal of the Lepidopterists' Society, 71(1): 1-11; doi: 10.18473/lepi.v71i1.a2

ELIOT, J.N. (1973): The higher classification of the Lycaenidae (Lepidoptera): a tentative arrangement. Bulletin of the British Museum of Natural History (Entomology), 28(6): 373-506, 6 pls., 162 figs., 4 tabs.

FRATELLO, S.A. (2003): Guyana expeditions (JanuaryApril 2001). News of the Lepidopterists' Society, 45(4): 109-111, 116-121, 9 figs., 1 map

FrATEllo, S.A. (2004): New species from Mt. Roraima. News of the Lepidopterists' Society, 46(4): 122-126, 10 figs.

FrATELlO, S.A. (2005): An expedition to Guyana's Acarai Mts. including two new and one undescribed butterfly species. News of the Lepidopterists' Society, 47(1): 29-31, 34-37, 12 figs.

Hoskins, A. \& BÁlint, Z. (2016): Arcas - A case of spider mimicry? (Lepidoptera: Lycaenidae: Theclinae: Eumaeini). Lepidoptera Novae, 9(1): 33-36.

IMAFUKU, M. \& KITAMURA, T. (2018): Preference of virgin females for male wing color in a sexually dichromatic butterfly, Pseudozizeeria maha (Lycaenidae). Journal of the Lepidopterists' Society, 72(3): 212-218. doi: 10.18473/lepi.v72i3.a6

JOHNSON, K.D. (1993): Neotropical hairstreak butterflies: New sister genera of the "Electrostrymon/ Angulopis" grade of Eumaeini (Lepidoptera, Lycaenidae, Theclinae). Reports of the Museum of Natural History. University of Wisconsin, (Stevens Point) 32: [i-ii], 1-76, [1-12], pls. 1-4, 11 figs.

KEMP, D.J. (2007): Female butterflies prefer males bearing bright iridescent ornamentation. Royal Society Proceedings of Biological Sciences, 274 (1623): 1043-1047. doi: 10.1098/rspb.2006.0043

Kertész, K., Piszter, G., HorvÁth, E.Zs., BÁlint, Zs. \& BIRÓ, L.P. (2017): Changes in structural and pigmentary colours in response to cold stress in Polyommatus icarus butterflies. Scientific Reports, 7: 1118. doi: 10.1038/s41598-017-01273-7

Kertész, K., Piszter, G., BÁlint, Zs. \& BIRÓ, L.P. (2019): Biogeographical patterns in the structural 
blue of male Polyommatus icarus butterflies. Scientific Reports, 9: 2338. doi: 10.1038/s41598-01938827-w

LAMAS, G. (2004): Nymphalidae. Ithomiinae. In. LAMAS, G. (Ed.), Checklist: Part 4A. Hesperioidea Papilionoidea. In. HEPPNER, J.B. (Ed.), Atlas of Neotropical Lepidoptera. Volume 5A. Gainesville, Association for Tropical Lepidoptera; Scientific Publishers, p. 172-191.

LATHY, P.I. (1932): The genus Lamprospilus (Lepidoptera). Annals and Magazine of Natural History, 9: 180-182.

Luke S., Vukusic, P. \& Hallam, B. (2009): Measuring and modeling optical scattering and the colour quality of white pierid butterfly scales. Optics Express, 17(17):14729-14743. doi: $\underline{\text { 10.1364/OE.17.014729 }}$

MORRONE, J.J. (2014): Biogeographical regionalisation of the Neotropical Region. Zootaxa, 3782(1): 1110. doi: 10.11646/zootaxa.3782.1.1

Morrone, J.J. (2017): Neotropical biogeography: Regionalization and evolution. CRC Press, Boca Raton, 312 pp.

Oláh J., Andersen, T., BeshKov,S., Ciubuc, C., COPPA, G., IBRAHIMI, H., KovÁCs,T., OlÁH, J. jr. \& SZCZESNY, B. (2018): Unified phylogenetic species concept: taking subspecies and race out of science: postmodern theory applied to the Potamophylax cingulatus group (Trichoptera, Limnephilidae). Opuscula Zoologica Budapest, 49(1): 33-70. doi: 10.18348/opzool.2018.1.133

Prieto, C. \& DAHners, H. (2006): Sección Morfología, Comportamiento, Ecología, Evolución y Sistemática Eumaeini (Lepidoptera: Lycaenidae) del cerro San Antonio: Dinámica de la riqueza y comportamiento de "Hilltopping". Revista Colombiana de Entomología, 32(2): 179-190.
PRIETO, C. \& DAHNERS, H. (2009): Resource Utilization and Environmental and Spatio-Temporal Overlap of a Hilltopping Lycaenid Butterfly Community in the Colombian Andes. Journal of Insect Science, 9: 16. doi: $\underline{10.1673 / 031.009 .1601}$

RobBIns, R.K. (2004): Lycaenidae. Theclinae. Tribe Eumaeini, In: LAMAS, G. (Ed.), Checklist: Part 4A. Hesperioidea - Papilionoidea. In: HEPPNER, J.B. (Ed.), Atlas of Neotropical Lepidoptera. Volume 5A. Gainesville, Association for Tropical Lepidoptera; Scientific Publishers, p. 118-137.

RoBBINS, R.K. \& BUSBY, R.C. (2009): Updated phylogeny, taxonomy, and diversification of Janthecla Robbins \& Venables (Lycaenidae: Theclinae: Eumaeini). Journal of Research on the Lepidoptera, 41: 5-13.

RobBins, R.K. \& DuARTE, M. (2010): A tale of two species: detritivory, parapatry, and sexual dimorphism in Lamprospilus collucia and L. orcidia (Lycaenidae: Theclinae: Eumaeini). Journal of Research on the Lepidoptera, 42: 64-73, 29 figs.

Rull, V., Vegas-Vilarrúbia, T., Huber, O. \& SEÑARIS, C. (Eds.) (2019): Biodiversity of Pantepui, the Pristine "Lost World" of the Neotropical Guiana Highlands. Elsevier-Academic Press, London, xviii $+452 \mathrm{pp}$.

Siddique, H.R., GOMARD, G. \& HöSCHLER, H. (2015) The role of random nanostructures for the omnidirectional anti-reflection properties of the glasswing butterfly. Nature Communications, 6: 6909. doi: $\underline{10.1038 / \text { ncomms } 7909}$

WARREN, A.D., DAVIS, K.J., STANGEland, E.M., PELHAM, J.P. \& GRISHIN, N.V. (2013): Illustrated Lists of American Butterflies. Available at http://www.butterfliesofamerica.com/ [accessed: 21.XII.2018].

WINTER, W.D. Jr. (2000): Basic techniques for observing and studying moths \& butterflies. Memoirs of the Lepidopterists' Society, 5: xviii + 444 pp. 